\title{
SCE- UA法を適用した分布型流出モデルの 代表パラメータ設定手法に関する検討 STUDY ON PARAMETER IDENTIFICATION OF DISTRIBUTED RUNOFFMODEL USING SCE-UA METHOD
}

\author{
松原隆之 ${ }^{1} \cdot$ 土田和稔 $2 \cdot$ 日比谷正則 3 \\ Takayuki MATSUBARA, Kazutoshi TSUCHIDA, and Masanori HIBIYA \\ 1正会員 工修 電源開発株式会社 土木建築部 ( T 104-8165 東京都中央区銀座6-15-1) \\ 2正会員＼cjkstart株式会社開発設計コンサルタント（１01-0021 東京都千代田区外神田2-16-2) \\ 3非会員＼cjkstart株式会社JPビジネスサービス（１355-8451 東京都江東区深川2-2-18)
}

\begin{abstract}
In recent years, rainfall forecasting technologies and runoff simulation models have been advanced remarkably and some dam inflow prediction methods using a distributed runoff model have been applied to dam operations practically.

In this study, the way to identify parameters of the distributed runoff model using the temporary parameters generated in the calculation process of the SCE-UA method (Shuffled Complex Evolution method developed at the University of Arizona) has been proposed and the applicability has been examined using the distributed runoff model applied to the Shingu river basin. Analyzed dam inflow identified parameters using this way shows good agreement with the observed one in many flood events.
\end{abstract}

Key Words: $\quad$ parameter identification, distributed rainfall runoff model, SCE-UA

\section{1.はじめに}

近年, 全国で異常な降雨・出水の頻度か増加する傾向 にある．電源開発(株)は全国に34ダムを有しており，今後， 「流域住民の安全・安心」と「水資源の有効利用」の両 面について継続して実現していくためには，より効率的 で弾力的な貯水池運用が求められ，信頼性の高いダム流 入量予測技術の導入が必要となる.

最近では , 降雨予測と流出解析モデルを組合せてダム 流入量を直接予測し, 実際のダム運用に活用する事例も 増えつつある . ダム流入量予測に適用する流出解析モデ ルについては, 流域を細分化し, 植生 , 地形 , 地質 , 降 雨分布特性等をより緻密に表現することで, 高い再現性 を確保できる分布型流出モデルの研究が進められている. 流出解析モデルの再現性はパラメータの設定精度に大き く影響され，従前，技術者力試行錯誤的にパラメータを 同定していたが , 分布型流出モデルはパラメータの種類 や計算点圷増加するためパラメータ同定か煩杂隹となると いう短所がある．ただし，最近では，モデルパラメータ を計算機で同定する手法か開発されており，例えば， SCE-UA法 ${ }^{1)}$, 遺伝的アルゴリズムによる手法 ${ }^{2)}$, 進化戦 略による手法 ${ }^{3)}$, 群知能最適化手法年等がある .
SCE-UA法を適用したパラメータ同定に関する研究と して , 高崎他 ${ }^{5}$ は , 都市型貯留関数モデルにおいてSCEUA法によるパラメータ同定を実施し，SCE-UA法の有効 性を評価している．また，檜山他 ${ }^{6}$ (は, 新宮川水系熊野 川流域を対象に，SCE-UA法による分布型流出モデルパ ラメータ同定と再現性評価を実施し，樣々な規模の洪水 イベントに対し, 共通的に再現性の高い代表パラメータ か存在する可能性を示唆している.

本検討では, ダム流入量予測精度向上検討の一方策と して分布型流出モデルの再現性を改善することを目的に， 複数の出水イベントに対して共通的に再現性の高い代表 パラメータをSCE-UA法を用いて設定する手法を考案し， 新宮川水系熊野川流域をモデルに光の適用性を評価した .

\section{2 . 検討手順}

本検討の手順を図-1に示す . まず , 新宮川水系熊野川 流域を対象とした分布型流出モデルを構筑した後 , 予備 検討として2つの代表出水を対象にSCE-UA法によるパラ メータ同定を実施し , パラメータ同定過程て甡み出され る暫定パラメータと午の再現性からSCE-UA法による同 定過程の特徵を確認した . 次に, 同定過程て確認された 


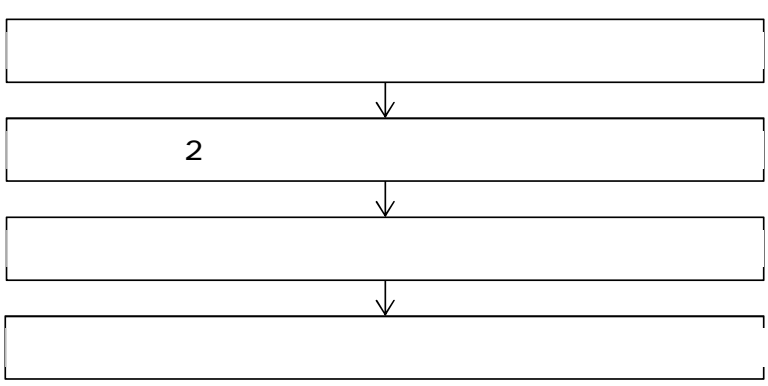

図 1 検討フロー

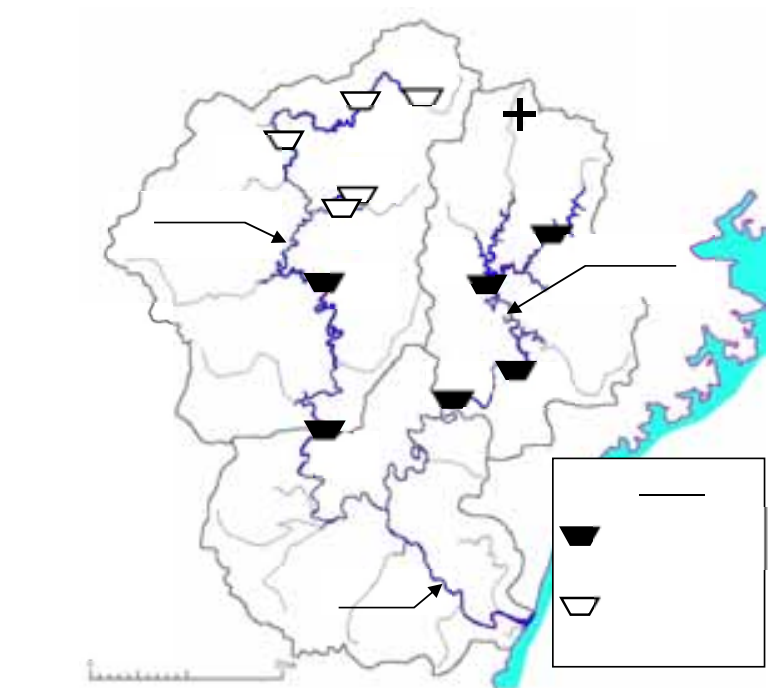

図- 2 熊野川流域におけるダムの位置

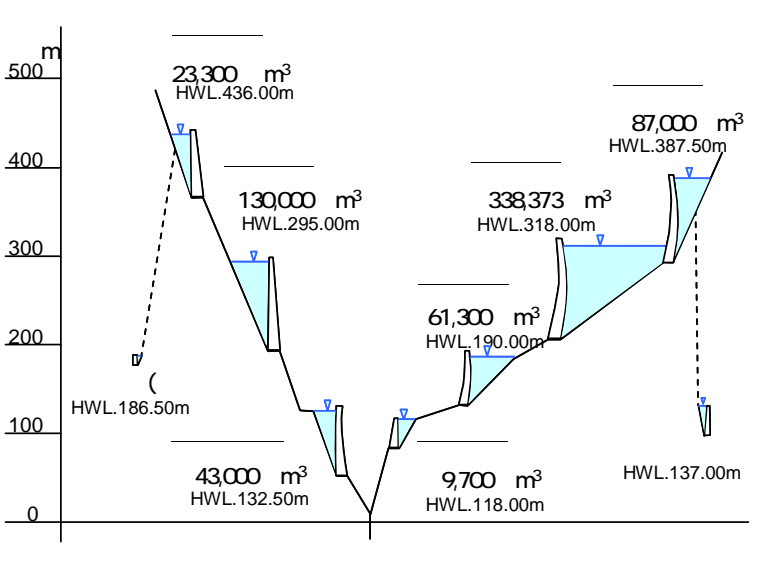

図－３熊野川流域のダムと総貯水容量

特徵を考慮した形で, 複数イベントに対し再現性の高い 代表パラメータの設定手法を検討した . 最後に , 考案し たパラメータ設定手法を適用したパラメータ同定と複数 イベントに対する再現性を確認し，考案したパラメータ 設定手法の適用性を評価した。

\section{3. 分布型流出モデルの構築}

(1) モデル流域の概要

新宮川水系熊野川のダムの位置を图一2に示す . 熊野川

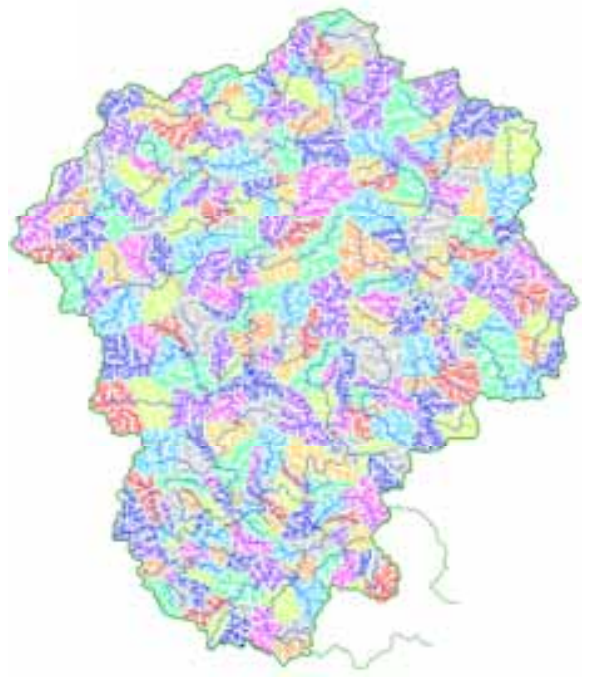

図-4 流域モデル模式図 (流水線網)

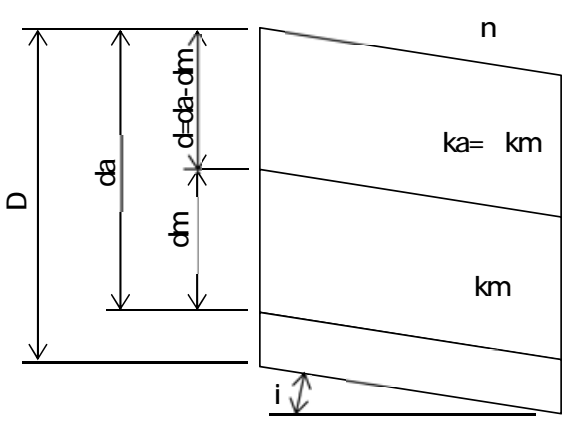

図-5 モデル概念及び主要パラメータ

は，紀伊半島南部を流れる流路延長 $183 \mathrm{~km}$ ，流域面積 2,360 $\mathrm{km}^{2}$ の1級河川で, 流域内に治水艾ムはなく，11ダ ムすべてか浰水専用公である.これらのダム群の内， 電源開発(株力発電を実施しているダムの概要を图-3に示 す . 池原ダム及び風屋ダムは総貯水容量が相対的に大き く弾力的な貯水池運用による効果力溡に期待できる .

\section{(2) モデルの構築}

本検討では，市川他》及ひ椎葉他 ${ }^{8}$ の分布型流出モデル を適用した .この分布型流出モデルでは，流域に降った 雨か斜面を流れる過程と, 斜面から流れ込んだ水が河道 を流れる過程を組合せて流域全体の水の流れを計算でき， ダム地点や任意の地点での河川流量を出力することがで きる.なお , 斜面部は飽和・不飽和流れを考慮した kinematic waveモデルを, 河道部は地表面流のkinematic waveモデルを適用している . また, 国土数値情報の河道

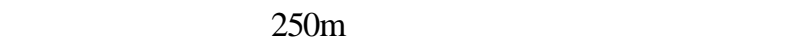
構筑システムGeoHyMoS ${ }^{8) 9}$ を用いて , 流域モデルを作成 した .構築した流域モデル，モデル概念図及び主要モデ ルパラメータを図-4及び図-5に示す。

(3) 流出解析条件

本検討では，気象庁のレーダーアメダス解析雨量を電 源開発(侏)力設置した地上雨量計の観測雨量で補正した雨 


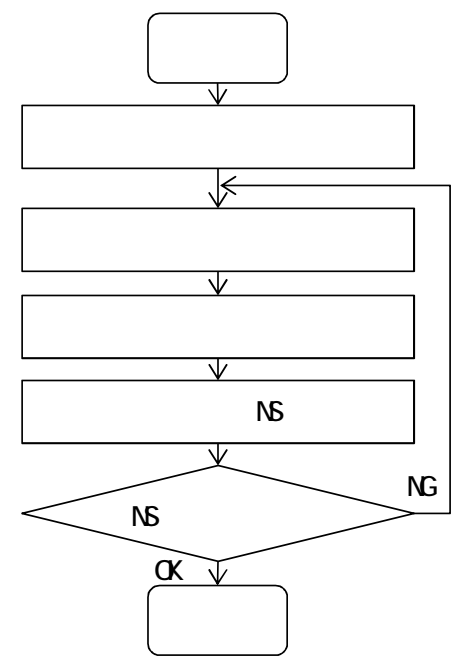

図- 6 SCE- UA法の同定計算概略フロー

表-1 同定パラメータの初期值及び上下限値

\begin{tabular}{|c|c|c|c|}
\hline & 初期值 & 下限值 & 上限值 \\
\hline $\mathrm{n}$ & 0.6 & 0.1 & 0.9 \\
\hline $\mathrm{km}(\mathrm{m} / \mathrm{s})$ & 0.01 & 0.0001 & 0.1 \\
\hline $\mathrm{d}(\mathrm{m})$ & 0.0001 & 0.0001 & 0.3 \\
\hline $\mathrm{dm}(\mathrm{m})$ & 0.45 & 0.0001 & 0.7 \\
\hline$\beta$ & 4 & 1 & 100 \\
\hline $\mathrm{D}(\mathrm{m})$ & 1.0 & - & - \\
\hline
\end{tabular}

量 (以下, 解析雨量という) を上記て設定したモデルに 入力して, 対象公地点における流量 (以下, 計算流量 という) を出力した.なお, 解析雨量は, レーダーアメ ダス解析雨量と地上雨量の雨量比を各観測ポイントで算 出し, メッシュ毎に空間内挿した雨量比をレーダーアメ ダス解析雨量に乗じて作成した . 対象ダムの上流域に電 源開発(森)管理する別の公がある場合は, 上流公ムの 実績放流量を河道上流端の境界条件として与えて流出計 算を実施した .なお，他社多ムはモデル化していない .

\section{(4) モデルの再現性評価指標}

モデルの再現性は, 対象ダム地点における計算流量と 実績流量を用い，Nash-Sutcliffe指標（以下，NS指標とい う）により評価することとした .一般的に，NS指標が 0.7以上の場合, 再現性が高いと考えることができる . NS指標の算出方法を以下に示す .

$$
\mathrm{NS}=1-\frac{\sum\left(Q_{o b}-Q_{c a l}\right)^{2}}{\sum\left(Q_{o b}-\bar{Q}_{o b}\right)^{2}}
$$

ここに， $\mathrm{Q}_{\mathrm{ob}}$ と $\mathrm{Q}_{\mathrm{cal}}$ はダム地点における毎正時の観測流 量及ひ計算流量で， $\bar{Q}_{o b}$ は観測流量の平均値である .

\section{4 . SCE- UA法によるパラメータ同定過程の特徵}

SCE-UA法によるパラメータ同定計算の概略フローを 図-6に示す．まず，同定パラメータの上下限值，NS指 標の収束条件 , 出力条件等の条件を設定して同定計算を 開始する . 同定計算では，NS指標が1.0に収束するよう

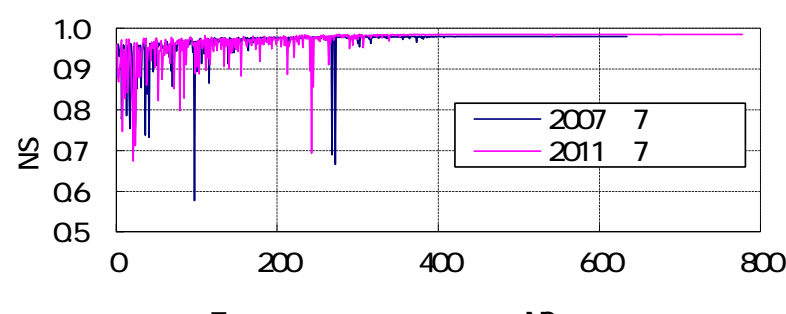

図-7 同定計算過程におけるNS指標の推移

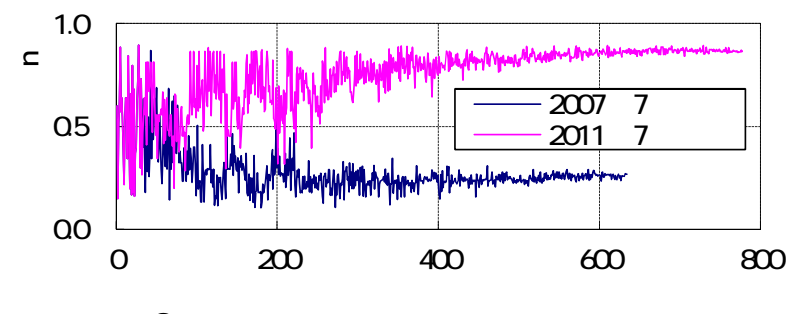

図-8 同定計算過程における斜面粗度係数nの推移

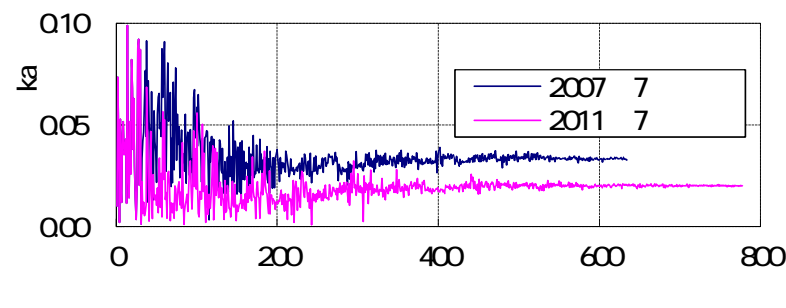

図-9 同定計算過程における透水係数kaの推移

に, 暫定パラメータの発行, 暫定パラメータによる流出 解析，NS指標による再現性評価を繰り返し実施する。 NS指標か収束した時点て計算を終了し，最終的な暫定 パラメータを最適パラメータとして得ることができる．

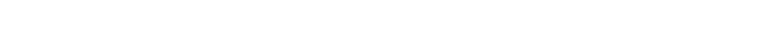
までの流域) を代表として , パラメータ同定過程で生成 される暫定パラメータと光のNS指標の推移を確認した . パラメータ同定は，2007年7月洪水 (台風 4 号) と2011年 7月洪水 (台風6号) の2イベントを対象に実施した . 同 定パラメータの種類, 初期値, 上下限值を表-1に示す . なお，本検討では，計算機能力を考慮しパラメータは流 域で一樣として同定計算を実施した .

同定計算過程におけるNS指標, 斜面粗度係数n, 透水 係数kaの推移を图-7〜9に示す.いずれのイベントも， 同定計算回数100回程度まではパラメータが大きく変動 しているが, 200回程度以上となると変動範囲が減少し て，最終的にNS指標が一般に再現性が良いとされる0.7 以上でパラメータが収束している。ただし，図-8の斜面 粗度係数nの収束值は, 2007年7月洪水力約0.3, 2011年7 月洪水か喲0.9となり，2つのイベントで大きく異なって いる.なお，弚の他のパラメータの挙動も概ね同樣であ ることを確認している.上記の原因としては，モデル誤 差や, 出水毎の観測誤差等を含めて最適化することか影 響しているものと考えられる . 上記より，個々の出水イ ベントにおいてSCE-UA法で同定された最終的な最適パ ラメータは, 他の出水イベントに対して必ずしも最適な パラメータではないことが分かる.

一方, 図-7 90収束前段階（概ね計算回数200回以下 


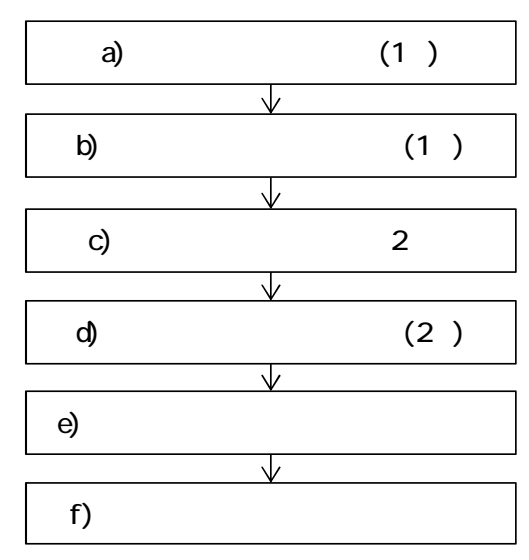

図-10 代表パラメータ設定の概略フロー
表- 2 代表パラメータ設定に用いた出水事例

\begin{tabular}{|c|c|c|c|c|c|c|}
\hline \multirow[b]{2}{*}{ 事 } & \multicolumn{3}{|c|}{ 降雨期間 } & \multicolumn{2}{|c|}{ 最大流入量 $\left(\mathrm{m}^{3} / \mathrm{s}\right)^{*}$} & \multirow[b]{2}{*}{$\begin{array}{l}\text { 出水 } \\
\text { 要因 }\end{array}$} \\
\hline & 年 & 開始 & 終了 & $\begin{array}{c}\text { 池原 } \\
\text { ダム }\end{array}$ & $\begin{array}{l}\text { 風屋 } \\
\text { ダム }\end{array}$ & \\
\hline 1 & 2001 & $06 / 18$ & $06 / 24$ & 1,564 & 3,236 & 前線 \\
\hline 2 & 2004 & $06 / 19$ & $06 / 21$ & 2,207 & 2,795 & 台風6号 \\
\hline 3 & 2004 & $09 / 27$ & $09 / 29$ & 3,337 & 983 & 台風21号 \\
\hline 4 & 2005 & $09 / 04$ & $09 / 07$ & 1,485 & 1,966 & 台風14号 \\
\hline 5 & 2007 & $07 / 11$ & $07 / 15$ & 1,576 & 2,205 & 台風4号 \\
\hline 6 & 2009 & $10 / 05$ & $10 / 08$ & 1,770 & 1,659 & 台風18号 \\
\hline 7 & 2011 & $07 / 17$ & $07 / 20$ & 3,280 & 2,788 & 台風6号 \\
\hline 8 & 2011 & $08 / 31$ & $09 / 05$ & 4,113 & 4,873 & 台風,12号 \\
\hline 9 & 2011 & 09/19 & 0921 & 3,743 & 1,663 & 台風15号 \\
\hline 10 & 2012 & $06 / 18$ & $06 / 22$ & 2,068 & 1,378 & 台風 4 号 \\
\hline 11 & 2012 & $09 / 29$ & $09 / 30$ & 2,708 & 1,211 & 台風17号 \\
\hline
\end{tabular}

c)イベント毎の同定計算(2次)

1次絞り込みて特定された斜面粗度係数nの範囲を上下 限值に設定して，再度，イベント毎に同定計算を実施し， 同定計算過程で生み出された暫定パラメータと年のNS 指標を出力する . なお, 斜面粗度係数以外のパラメータ の上下限値は変更しない .

d)斜面粗度係数範囲の絞込み(2次)

同定計算 (2次) で得られた全計算結果から，1次絞込 みと同樣に，斜面粗度係数nの存在範囲を絞り込む．2次 絞り込みでは，同定計算で得られた暫定パラメータにつ いて, 斜面粗度係数口を 0.01 刻みの範囲で区分・整理す る.以下，1次絞込みと同樣にして，再現性力平均的に 最も高いと考えられる斜面粗度係数nの範囲を特定する．

e) 代表パラメータ候補による再現解析

特定された斜面粗度係数nの範囲内の各イベントの暫 定パラメータの中から，NS指標が最も大きい暫定パラ メータを代表パラメータ候補として抽出し, 各代表パラ メータ候補て他のイベントの再現解析を実施する。

f) 再現性評価・代表パラメー夕決定

再現解析結果のNS指標から再現性を評価し，複数の イベントに対して最も再現性が高くなったパラメータを 代表パラメータとする .

\section{6 . 代表パラメータ設定手法の適用性評価}

b)斜面粗度係数範囲の絞込み(1次)

得られた全計算結果について, 斜面粗度係数んとNS指 標に着目し, 最適な斜面粗度係数nの存在範囲を絞り込 む·具体的には，まず，同定計算で得られた暫定パラ メータについて, 斜面粗度係数 $n$ を 0.1 刻みの範囲で区 分・整理する．次に，区分された斜面粗度係数nの範囲 毎にNS指標が最大となった暫定パラメータを各イベン 卜て抽出する . 最後に，抽出された暫定パラメータの再 現解析結果の比較から，NS指標，最大流入量及び総流 入量等の再現性力平均的に最も高いと考えられる斜面粗 度係数nの範囲を特定する。
上記の代表パラメータ設定手法に基づき，5ダム流域

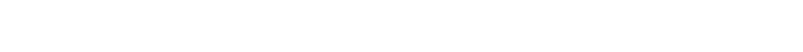
ム) の代表パラメータを設定した . 本検討では，特に池 原ダム及び風屋ダムにおける洪水時の流入量予測精度の

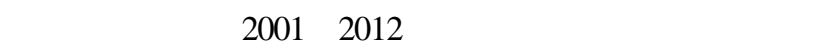
屋公流入量が洪水相当 (最大流入量 $1,500 \mathrm{~m}^{3} / \mathrm{s}$ 以上) となった16出水を抽出した . 次に , 各出水の流出率を考 慮の上, 選定する出水の最大流入量が偏らないようにし て, 最終的な同定対象の出水として11出水を選定した . 代表パラメータ設定に用いた出水事例を表-2に示す． 
表- 3 設定された代表パラメータ

\begin{tabular}{|c|c|c|c|c|c|c|}
\hline ダム流域 & $\mathrm{n}$ & $\mathrm{ka}$ & $\mathrm{km}$ & $\mathrm{da}$ & $\mathrm{dm}$ & $\mathrm{D}$ \\
\hline 風屋ダ & 0.560 & 0.062 & 0.006 & 0.556 & 0.271 & 1.0 \\
\hline 二津野ダム & 0.580 & 0.067 & 0.004 & 0.690 & 0.681 & 1.0 \\
\hline 池原ダム & 0.511 & 0.016 & 0.001 & 0.670 & 0.612 & 1.0 \\
\hline 七色ダム & 0.530 & 0.028 & 0.001 & 0.725 & 0.672 & 1.0 \\
\hline 小森ダム & 0.512 & 0.077 & 0.004 & 0.604 & 0.372 & 1.0 \\
\hline
\end{tabular}

考案した代表パラメータ設定手法て導出された代表パ ラメータを表-3に示す . 代表パラメータは各流域て概ね 同程度の值となった . 特に斜面粗度係数 $\mathrm{n}$ は $0.511 〜 0.560$

(森林の一般値0.6) となり，概ね妥当な値であると考 えられる.なお, 斜面粗度係数nと飽和透水係数kaが,

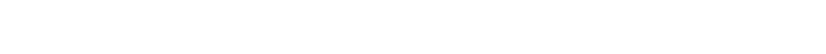
上，表面流出しやすく表現される結果となった . 実際に， 十津川筋よりも北山川筋の流域の方が岩の露出が多く見 られることから, 同定された代表パラメータから実際の 流出特性を推定できる可能性があると考えられる .

次に, 設定されたパラメータの再現性を複数の出水で 確認するため, 上記の代表出水 (11出水) と, 代表パラ メータ設定では適用していない关の他出水 (26出水) に つい, 導出された代表パラメータでの再現解析を実施 し, 弚の再現性を評価した . なお, 弚の他出水とは,

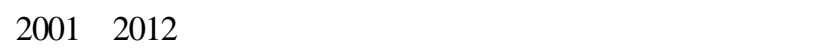
か $500 \mathrm{~m}^{3} / \mathrm{s}$ 以上となった37出水のうち代表11出水を除い た26出水である. 再現性評価結果を图-11〜15に示す． 代表11出水のNS指標は0.7以上となり，複数の大規模な 出水に対して, 同定された代表パラメータは非常に高い 再現性を有していることが分かる．また，弚の他出水

(26出水) については, 最大流入量 $1,500 \mathrm{~m}^{3} / \mathrm{s}$ 以下の小規 模出水でNS指標が0.7以下となった出水もあるが , ほと んどはNS指標が0.7以上となり，高い再現性を有してい ると考えられる．なお，十津川筋の風屋多ム及び二津野 ダム (図-11及び図-12) では, 北山川筋の池原ダム , 七 色公, 小森多么 (図-13, 図-14, 図-15) よりもNS指 標が 0.7 を回る小規模出水の数が多い. モデル上, 風 屋公上流域に設置された他社多をを考慮していないた め, 小規模出水では上流文ムの貯留の効果か㳔象2各ム の計算流量と観測流量の承離に影響しているものと考え

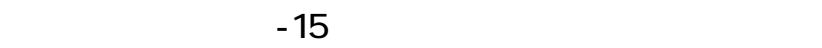
結果か相対的に高いが, 小森公流域は他の流域に比へ て流域面積が小さ，計算流入量に占める七色多的ら の放流量 (観測流量) の割合が大きいため，他のダム流 域よりも相対的にNS指標が大きくなったと考えられる． 上記より，父么流入量を予測する場合，対象出水規模が 小さい場合や，流域面積が小さい場合は，上流么の影 響を考慮し, 上流公の放流操作を定式化する等して精

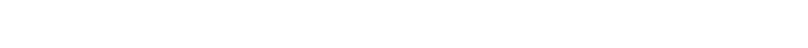

再現解析結果の代表例として, 池原ダムの観測流量と 計算流量を比較したハイドログラフを図-16〜18に示す． 图-16の2011年台風12号出水は既往最大の出水, 図-17の

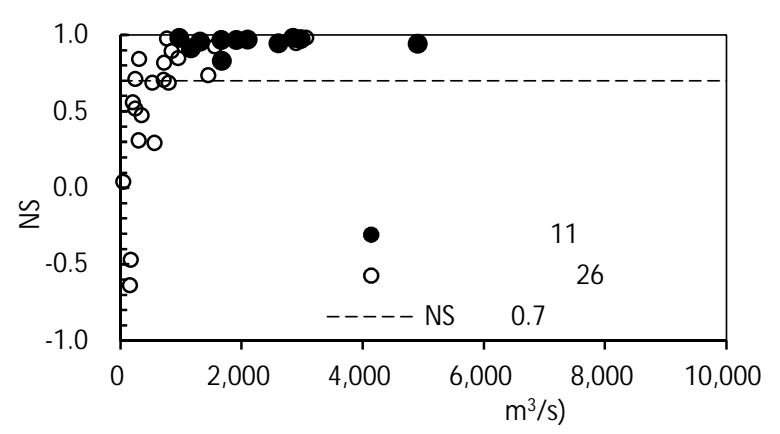

図-11 風屋ダム流域モデルの再現性評価結果

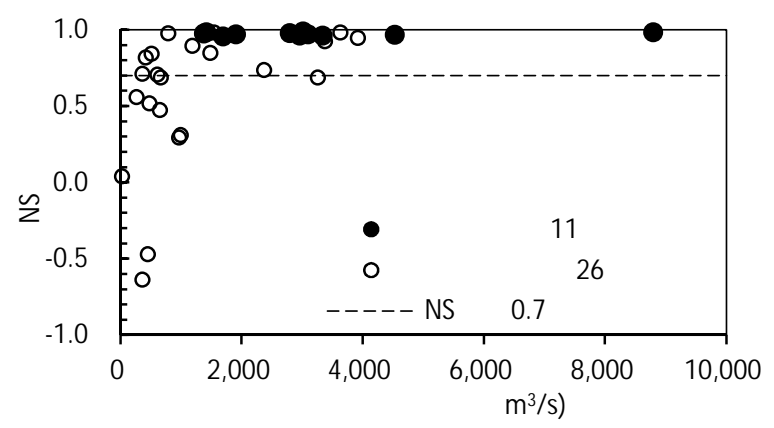

図-12 二津野ダム流域モデルの再現性評価結果

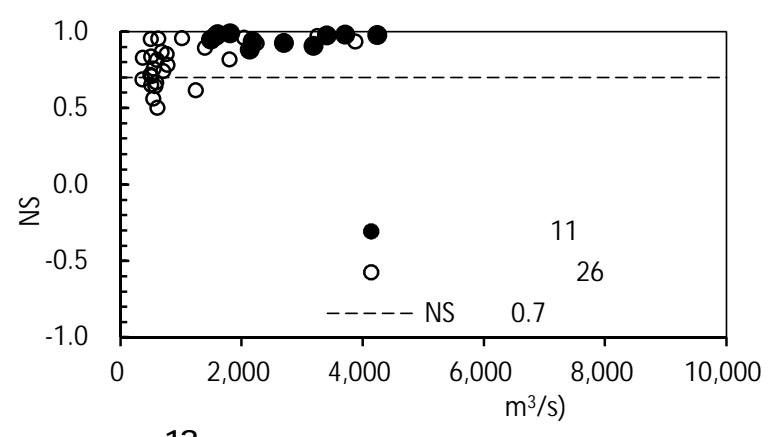

図-13 池原ダム流域モデルの再現性評価結果

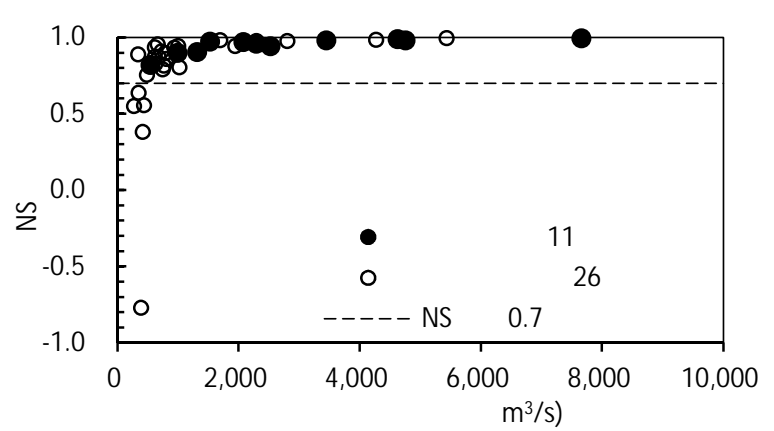

図-14 七色ダム流域モデルの再現性評価結果

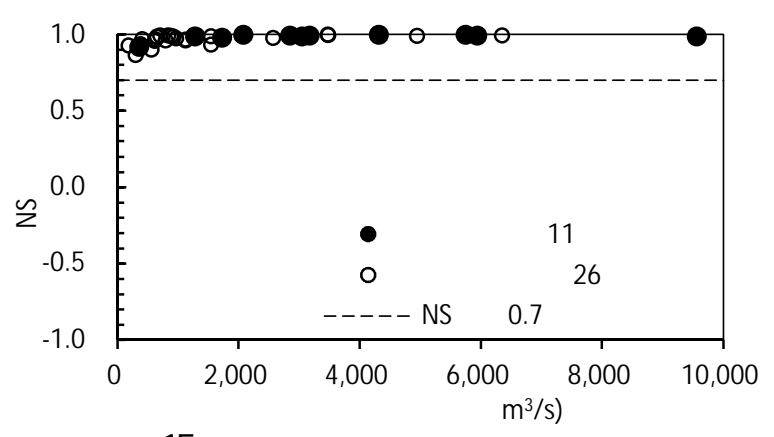

図 15 小森ダム流域モデルの再現性評価結果 


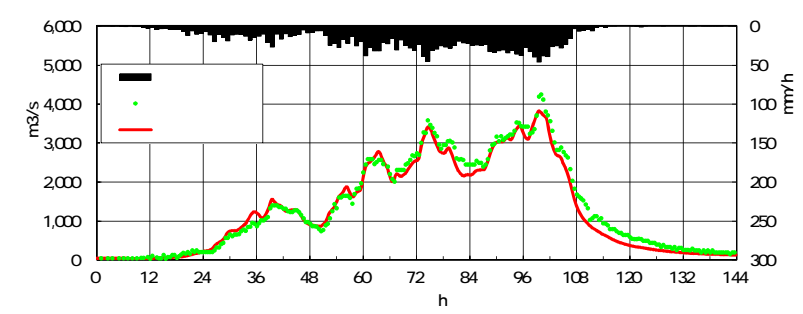

図- 16 池原ダム流入量再現結果 (2011年台風12号時)

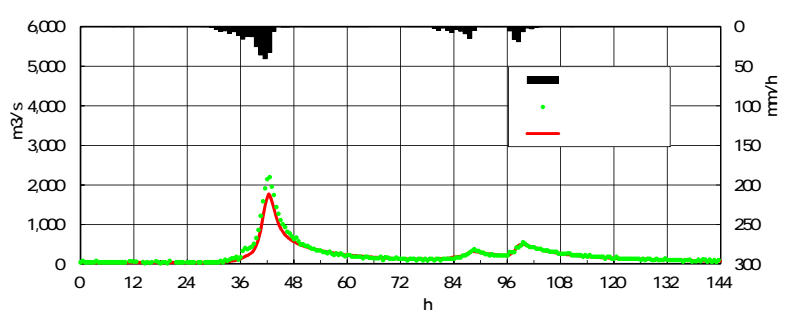

図-17 池原ダム流入量再現結果 (2012年台風4号時)

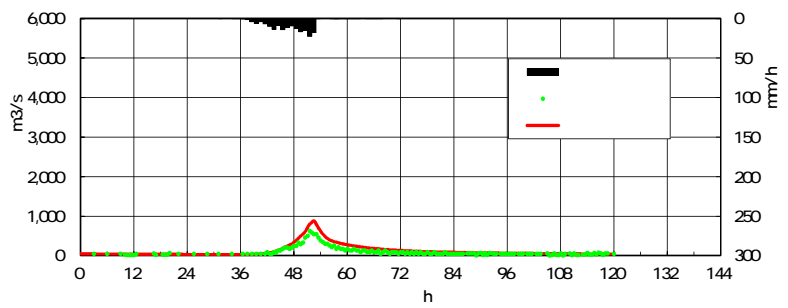

図-18 池原ダム流入量再現結果 (2004年12月出水時)

2012 年台風 4 号出水は最大流入量約 $2,000 \mathrm{~m}^{3} / \mathrm{s}$ クラスの出 水, 図-18の2004年12月出水 (低気圧性の出水) は最大 流入量 $1,000 \mathrm{~m}^{3} / \mathrm{s}$ 以下クラスの出水である . 図より , 同定 計算対象外の2004年12月出水を含め, 多少の誤差はある ものの，いずれの出水も高い再現性を有していることが 分かる. なお, 他の出水事例及び他の㕛么地点において も同程度の誤差及び再現性を有していることを確認して いる、以上より，本検討で考案したSCE-UA法を用いた 代表パラメータ設定手法の適用により，熊野川流域を対 象とした分布型流出モデルに対し, 複数の取水に対して 高い再現性を有する代表パラメータを設定でき，本手法 か洧効であるものと考えられる .

\section{7 .まとめ}

本研究における主要な成果を以下に示す.

(1)分布型流出モデルの同定にSCE-UA法を適用した場合， ある出水の最適パラメータは, 他の出水では最適では ない場合がある .一方，同定過程で生成される暫定パ ラメータの中にはNS指標が0.7以上で再現性が高く， 複数イベント間で差がないものがある.したがって， 暫定パラメータの中からより再現性の高い代表パラ メータを抽出できる可能性があることが分かった .

(2)SCE-UA法による同定過程で生成される暫定パラメー 夕の中から複数の出水で再現性の高い代表パラメータ を抽出する手法を考案し，熊野川流域を対象とした分
布型流出モデルのパラメータ同定を実施した . 同定さ れた代表パラメータの再現性を評価した結果, 大規模 な出水から小規模な出水まで, 概ね良好な再現性力確 認でき，考案した手法か洧効であることが分かった .

(3)適切に設定された代表パラメータから対象流域の流域 特性を把握できる可能性があることが分かった .

今後は，本検討て考案した手法を他の流域にも適用し， 手法の適用性検証と更なる再現性向上方法を検討すると ともに, 同定結果と実際の流域特性 (土地利用や土質等) との関係性を調査する計画である．また，実際に本手法 を適用した分布型流出モデルによるリアルタイムでのダ 公流入量予測に取組み，実際のダム運用への活用方法の 検討を進める計画である .

謝辞 : 本検討の実施に当たっては, 京都大学 立川康人 教授のこ指導いただきましたこと，ここに記して感謝の 意を表します．

\section{参考文献}

1) Duan, Q., Sorooshian, S. and Gupta, V.K. : Optimal use of the SCE-UA global optimization method for calibrating watershed models , Journal of Hydrology , Vol. 158 ，265-284 , 1994

2) 田中丸治哉 : タンクモデル定数の大域的探索 , 農業土木学会 論文集，Vol.178，103-112，1995

3) 藤原洋一, 田中丸治哉, 畑武志, 多田明夫 : 進化戦略による 流出モデル定数の最適化, 農業土木学会論文集, Vol.227, 119-129 , 2003

4) 小槻峻司, 田中賢治, 小尻利治, 浜口俊雄 : 群知能最適化手 法を用いた分布型流出モデルのパラメーター同定 : 土木学会 論文集B1，Vol.68，523-528，2012

5) 高崎忠勝, 河村明, 天口英雄, 荒木千博 : 都市の流出気候を 考慮した新たな貯留関数モデルの提案, 土木学会論文集B, Vol.65 , No.3 , 217-230 , 2009

6) 檜山航平, 立川康人, Kim Sunmin, 萬和明, 椎葉充晴: 分 布型流出モデルを用いた熊野川における既往最大級の洪水の 再現性分析, 土木学会年次学術講演会概要集, Vol.68, 251252,2013

7) 市川温, 村上将道 , 立川康人 , 椎葉充晴 : 流域地形の新たな 数理表現形式に基づく流域流出系シミュレーションシステム の開発，土木学会論文集，No.691/II-57，43-52，2001

8) 椎葉充晴, 立川康人, 市川温 : 水文学・水工計画学, 京都大 学学術出版会, 2013

9) 京都大学大学院工学研究科社会基盤工学専攻水文 ·水資源学 分野: 流域地形情報を基盤とした水文モデルシステムGeoHy MoS , http://hywr.kuciv.kyoto-u.ac.jp/geohymos/geohymos.html

10)佐山敬洋, 立川康人, 寶馨 : 流出モデルの不確実性評価手 法と光のモデル選択への適用, 土木学会論文集, No.789/II71 , 1-13 , 2005

(2014.9.30受付) 